\title{
Kelayakan Novel Anak Rantau Karya Ahmad Fuadi sebagai Bahan Ajar Apresiasi Sastra
}

\author{
Rifky Yulistiawan, Nas Haryati Setyaningsih \\ Universitas Negeri Semarang \\ rifkyyulistiawan10@gmail.com
}

\section{Sejarah Artikel}

diterima 13/09/2019

\begin{abstract}
The lack of use of new novels as literary teaching materials in high school is the background of this research. This research aims to determine the feasibility of the novel Anak Rantau by Ahmad Fuadi as a teaching material for literary appreciation for high school. This research uses descriptive qualitative research methods. The data collection technique used is the documentation technique, while the data analysis technique uses the Miles and Huberman model. The results of this research indicate, when viewed from aspects of language, psychological of the reader, cultural background, and its suitability with 2013 curriculum demands of Indonesian Language (KD and character education), novel Anak Rantau is worthy of being used a teaching material of literary appreciation for high school. Based of the results of that research, can be concluded novel Anak Rantau by Ahmad Fuadi worthy to be used as teaching material for literary appreciation for high school.

Keywords: novel, teaching material, literary appreciation.
\end{abstract}

\begin{abstract}
Abstrak
Kurangnya penggunaan novel baru sebagai bahan ajar sastra di SMA menjadi latar belakang penelitian ini. Penelitian ini bertujuan untuk mengetahui kelayakan novel Anak Rantau karya Ahmad Fuadi sebagai bahan ajar apresiasi sastra untuk SMA. Penelitian ini menggunakan metode penelitian deskriptif kualitatif. Teknik pengumpulan datanya menggunakan teknik dokumentasi, sedangkan teknik analisis datanya menggunakan model Miles dan Huberman. Hasil penelitian ini menunjukkan, jika ditinjau dari aspek kebahasaan, psikologi pembaca, latar belakang budaya, dan kesesuaiannya dengan tuntutan kurikulum 2013 Bahasa Indonesia (KD dan pendidikan karakter), novel Anak Rantau layak dijadikan bahan ajar apresiasi sastra untuk SMA. Berdasarkan hasil penelitian yang demikian, dapat disimpulkan novel Anak Rantau karya Ahmad Fuadi layak dijadikan sebagai bahan ajar apresiasi sastra untuk SMA.

Kata kunci: novel, bahan ajar, apresiasi sastra.
\end{abstract}

e-ISSN 2581-1835

p-ISSN 2581-1843

This work is licensed under a Creative Commons Attribution-ShareAlike 4.0 International License. 


\section{PENDAHULUAN}

Apresiasi sastra merupakan salah satu lingkup materi sastra yang sangat penting untuk dibelajarkan. Hal tersebut terbukti dengan adanya lingkup materi berupa tanggapan terhadap karya sastra dan menilai karya sastra (Kemendikbud, 2016:3). Pada dasarnya, apresiasi sastra adalah kegiatan menggauli karya sastra secara sungguh-sungguh sehingga menumbuhkan pengertian, penghargaan, kepekaan pikiran kritis, dan kepekaan perasaan yang baik terhadap karya sastra (Effendi dalam Aminuddin, 2015:35).

Salah satu jenis karya sastra yang menjadi tuntutan kurikulum 2013 dan wajib dipelajari oleh peserta didik SMA adalah novel. Novel adalah karya sastra yang di dalamnya berisi cerita tentang kehidupan baik secara alur cerita maupun tokoh-tokoh yang ditampilkan, karena biasanya merupakan cerita yang diangkat dari peristiwa yang terjadi dalam kehidupan (Praptiwi, 2017:236).

Pada masa sekarang ini telah banyak novel yang beredar di pasaran, baik itu novel lama ataupun novel baru. Namun sayangnya hal tersebut tidak diimbangi dengan banyaknya novel baru yang dijadikan sebagai bahan ajar apresiasi sastra di SMA. Padahal, apresiasi novel merupakan salah satu tuntutan mata pelajaran Bahasa Indonesia di SMA. Hal itu dibuktikan dengan adanya tuntutan KD-KD terkait apresiasi novel pada tingkat tersebut, seperti KD 3.9, 4.9, 3.18, dan 4.18 kelas X; KD 3.11, $4.11,3.20$, dan 4.20 kelas $\mathrm{XI}$; serta KD 3.3, 4.3, 3.4, 4.4, 3.8, 4.8, 3.9, dan 4.9 kelas XII.

Bahan ajar apresiasi adalah bahan ajar yang digunakan oleh pendidik untuk membelajarkan perihal apresiasi sastra kepada peserta didiknya. Selain itu juga dapat diartikan sebagai segala bentuk bahan yang digunakan untuk membantu pendidik dalam melaksanakan proses pembelajaran apresiasi sastra.

Berdasarkan hasil pengamatan dan wawancara tentang penggunaan novel sebagai bahan ajar apresiasi sastra di SMA Ibu Kartini Semarang, belum ditemukan fakta adanya penggunaan novel baru sebagai bahan ajar apresiasi sastra. Novelnovel yang digunakan masih termasuk dalam kategori novel lama dan menengah. Selain itu juga terkesan novel yang itu-itu saja, seperti AyatAyat Cinta (2004), $5 \mathrm{~cm}$ (2005), dan Laskar Pelangi (2005).

Tidak hanya di SMA Ibu Kartini Semarang, fakta yang mengkhawatirkan terkait penggunaan novel sebagai bahan ajar apresiasi sastra juga dapat ditemukan dalam buku teks Bahasa Indonesia kelas XI SMA (2017) dan XII SMA (2018). Fakta yang dimaksud yaitu belum adanya penggunaan novel baru sebagai bahan ajar apresiasi novel dalam buku-buku tersebut. Dalam buku teks Bahasa Indonesia kelas XI SMA tahun 2017 novel-novel yang ditemukan yaitu novel Saksi Mata (Petualangan Bocah di Zaman Jepang) (2002); Laila Madjnoen (Tjeritera di Tanah Arab) (1932); Laila Majnun karya Nizami (2002); Layla Majnun, Roman Cinta Paling Populer \& Abadi (2002); Tuilet (2009); dan Perahu Kertas (2010). Sementara pada buku teks Bahasa Indonesia kelas XII SMA tahun 2018, novelnovel yang ditemukan yaitu novel Pangeran Diponegoro "Menggagas Ratu Adil" (2007), Rumah Kaca 
(1988), Mangir (2000), Bumi Manusia (1980), Ronggeng Dukuh Paruk (1982), Gajah Mada Bergelut dalam Tahta dan Angkara (2006), dan Laskar Pelangi (2005).

Selain dalam buku teks Bahasa Indonesia kelas XI SMA (2017) dan XII SMA (2018), dalam buku teks Bahasa Indonesia kelas X (2016) juga ditemukan fakta yang sama, bahkan lebih mengkhawatirkan. Fakta yang dimaksud yaitu dalam buku teks tersebut tidak memuat teks yang berkaitan dengan novel sama sekali. Padahal novel juga menjadi tuntutan pembelajaran yang wajib dipelajari oleh peserta didik kelas X SMA.

Melihat kenyataan di lapangan yang demikian, dapat dikatakan sekarang ini dunia pendidikan Bahasa dan Sastra Indonesia sedang berada dalam kondisi yang memprihatinkan karena novel-novel yang digunakan sebagai bahan ajar apresiasi sastra kebanyakan adalah novel yang termasuk dalam kategori lama dan menengah. Hal tersebut bukanlah hal yang salah, namun akan lebih baik jika banyak pula bahan ajar apresiasi sastra yang berupa novel baru. Terlebih lagi, salah satu hal yang harus diperhatikan dalam pembelajaran sastra adalah perkembangan kesastraan.

Berkaitan dengan masalah yang telah dipaparkan sebelumnya, seharusnya perlu diadakan inovasi berupa pengadaan novel baru oleh pendidik sebagai bahan ajar apresiasi sastra yang tentunya harus sesuai dengan tuntutan dunia pendidikan dan kriteria kelayakan bahan ajar apresiasi sastra. Terlebih lagi sekarang ini sudah banyak novel baru yang memiliki kualitas yang bagus, bahkan tidak menutup kemungkinan ada novel baru yang dapat dijadikan sebagai bahan ajar apresiasi sastra. Salah satunya novel yang berjudul Anak Rantau karya Ahmad Fuadi.

Ahmad Fuadi adalah salah satu sastrawan yang sangat baik dalam menciptakan suatu novel. Dia juga pernah meraih banyak penghargaan bergengsi mulai dari Liputan 6 Award sampai Penulis Terbaik IKAPI. Salah satu karyanya yang fenomenal adalah novel Negeri 5 Menara. Novel tersebut telah berhasil meraih penghargaan Mega Bestseller. Selain itu melalui penelitian yang dilakukan oleh Wicaksono pada tahun 2014 novel tersebut terbukti juga memiliki kelayakan untuk dijadikan sebagai bahan ajar apresiasi sastra di SMA.

Selain novel Negeri 5 Menara, Fuadi juga menciptakan novel lain yang berjudul Anak Rantau. Novel tersebut diterbitkan pertama kali pada tahun 2017 dan telah berhasil meraih penghargaan National Bestseller. Sebagai salah satu novel yang telah meraih penghargaan tersebut, tentu novel ini dapat dikatakan memiliki kualitas yang baik. Novel tersebut merupakan novel yang berisi kisah seorang anak yang dapat dijadikan pembelajaran terkait kehidupan oleh pembacanya. Pemilihan bahasa yang digunakan oleh Fuadi dalam novel ini juga terbilang baik, yaitu menggunakan bahasa Indonesia yang sudah lazim (umum). Selain itu, dalam novel tersebut juga banyak ditemukan kosakata variatif yang dapat memperkaya perbendaharaan kata pembacanya. Latar belakang budaya yang diambil Fuadi dalam novel ini adalah daerah Minang, salah satu daerah yang ada di Indonesia.

Berdasarkan uraian singkat tentang novel Anak Rantau yang telah dipaparkan sebelumnya, tidak menutup kemungkinan novel tersebut memiliki potensi untuk dijadikan bahan ajar apresiasi sastra tingkat SMA. 
Adanya kemungkinan tersebut membuat peneliti merasa perlu melakukan sebuah analisis yang lebih mendalam terhadap novel tersebut. Dengan demikian, permasalahan yang dikaji dalam penelitian ini adalah bagaimana kelayakan novel Anak Rantau karya Ahmad Fuadi sebagai bahan ajar apresiasi sastra untuk SMA jika ditinjau berdasarkan beberapa aspek yang menjadi kriteria kelayakan bahan ajar sastra. Aspek- aspek yang dimaksud yaitu aspek kebahasaan, aspek psikologi (pembaca), aspek latar belakang budaya, dan aspek kesesuaian novel tersebut dengan tuntutan kurikulum 2013 (KD dan pendidikan karakter). Dengan kata lain, tujuan penelitian ini adalah untuk mengetahui kelayakan novel Anak Rantau karya Ahmad Fuadi jika dijadikan sebagai bahan ajar apresiasi sastra tingkat SMA.

\section{METODE}

Penelitian ini berjenis penelitian kualitatif dengan metode penelitian deskriptif kualitatif. Sumber datanya berupa novel Anak Rantau karya Ahmad Fuadi, cetakan kelima. Sesuai dengan sumber datanya, wujud data dalam penelitian ini adalah kata-kata, kalimat-kalimat, dialog-dialog, atau kutipan-kutipan dari novel tersebut.

Dalam penelitian ini instrumen penelitian yang digunakan adalah human instrument. Teknik pengumpulan datanya menggunakan teknik dokumentasi, sedangkan teknik analisis datanya menggunakan model Miles dan Huberman yang terdiri atas tiga langkah, yaitu data reduction, data display, dan conclusion drawing /verification (Sugiyono, 2016:337).

\section{PEMBAHASAN}

Kelayakan novel Anak Rantau karya Ahmad Fuadi sebagai bahan ajar apresiasi sastra untuk SMA dapat diketahui dengan cara menganalisis novel tersebut berdasarkan beberapa aspek kriteria kelayakan bahan ajar sastra. Menurut Rahmanto (1988:27) ada tiga aspek yang harus diperhatikan saat memilih bahan ajar sastra, yaitu aspek bahasa, psikologi, dan latar belakang budaya. Selain itu, aspek lain yang harus diperhatikan yaitu kesesuaian bahan ajar tersebut dengan tuntutan kurikulum 2013 Bahasa Indonesia (KD dan nilai pendidikan karakter). Berikut ini adalah paparan hasil analisis kelayakan novel Anak Rantau sebagai bahan ajar ditinjau dari aspek-aspek yang telah dipaparkan sebelumnya.

\section{Ditinjau dari Aspek Kebahasaan}

Menurut Rahmanto (1988:27) salah satu indikator bahan ajar sastra yang baik adalah bahan ajar yang bahasanya sesuai dengan tingkat penguasaan bahasa peserta didiknya. Berdasarkan analisis yang telah dilakukan, dalam novel Anak Rantau ditemukan adanya penggunaan aspek kebahasaan yang sesuai dengan tingkat penguasaan bahasa peserta didik SMA, beberapa aspek kebahasaan yang dimaksud yaitu (1) kata arkais; (2) kalimat kompleks; (3) kosakata yang variatif; dan (4) gaya 
bahasa yang variatif. Selain itu, dalam novel Anak Rantau juga ditemukan hal lain terkait aspek kebahasaan yang mampu mendukung kelayakan novel tersebut jika dijadikan sebagai bahan ajar sastra. Hal yang dimaksud yaitu (1) tidak ditemukan satuan bahasa yang bernilai kasar; dan (2) tingkat keterbacaan yang sesuai untuk peserta didik SMA.

\section{Penggunaan Kata Arkais}

Dalam novel Anak Rantau terdapat 123 data penggunaan kata arkais. Salah satu kata arkais yang ditemukan dalam novel ini adalah kata kesam. Penggunaan kata tersebut dapat terlihat melalui bukti kutipan "... Demikian dalam kesam kesumatnya pada segala yang di kampung sehingga tujuh belas tahun dia menolak pulang. ..." (Fuadi, 2018:17). Kata kesam yang terlihat dalam kutipan tersebut merupakan kata yang berasal dari bahasa Indonesia (baku), yang memiliki arti 'dendam'.

Tidak hanya kata kesam, dalam novel ini masih banyak lagi kata arkais yang ditemukan, seperti mitraliur 'senapan mesin', lancung 'curang', gaek 'tua sekali', dan lain-lain. Adanya penggunaan kata arkais yang cukup banyak dalam novel Anak Rantau, membuat novel ini memiliki nilai plus jika dijadikan bahan ajar apresiasi sastra di tingkat SMA. Hal tersebut karena, dengan adanya penggunaan aspek kebahasaan yang demikian, akan membuat novel ini memiliki kesesuaian dengan tingkat penguasaan bahasa yang dimiliki oleh peserta didik SMA (tahap kompetensi lengkap: lancar, fasih, dan terus berkembang menuju ke arah kompetensi berbahasa secara lengkap).
Penggunaan Kalimat Kompleks

Dalam novel Anak Rantau
ditemukan adanya penggunaan beberapa kalimat kompleks, seperti kalimat majemuk kompleks; majemuk setara (yang tergolong panjang atau rumit); majemuk bertingkat (yang tergolong panjang atau rumit); dan tunggal (yang panjang dan rumit).

Adanya penggunaan beberapa kalimat kompleks yang demikian, membuat novel Anak Rantau memiliki nilai plus jika dijadikan bahan ajar apresiasi sastra untuk SMA. Hal tersebut karena, dengan adanya penggunaan kalimat kompleks tersebut, novel ini memiliki kesesuaian dengan tingkat penguasaan bahasa peserta didik SMA.

\section{Penggunaan Kosakata yang Variatif}

Dalam novel Anak Rantau ditemukan 19 data yang meliputi 3 data penggunaan kosakata bahasa Arab dan 16 data penggunaan kosakata bahasa Minang. Salah satu contoh penggunaan kosakata bahasa Arab dalam novel ini dapat terlihat melalui kutipan "... Siapa tahu karena ini dia akan dicatatkan malaikat sebagai orang yang gugur fi sabilillah. Surga ganjarannya." (Fuadi, 2018:3). Dalam kutipan tersebut, kosakata bahasa Arab yang digunakan yaitu $f i$ sabilillah yang berarti 'orang yang berjuang di jalan Allah dan ketika meninggal mendapatkan surga sebagai balasan atau ganjarannya'. Sedangkan salah satu contoh penggunaan kosakata bahasa Minang dapat terlihat melalui kutipan "'Lai takana juo jalan pulang_wa'ang. ..." (Fuadi, 2018:19). Dalam kutipan tersebut, kosakata bahasa Minang yang digunakan dapat terlihat pada kalimat lai takana juo jalan pulang, 
yang dapat diartikan 'masih ingat juga kamu jalan pulang rupanya'.

Adanya penggunaan kosakata variatif yang demikian, membuat novel Anak Rantau memiliki nilai plus jika dijadikan bahan ajar apresiasi sastra untuk SMA. Hal tersebut karena dengan adanya penggunaan kosakata tersebut, novel Anak Rantau memiliki kesesuaian dengan tingkat penguasaan bahasa peserta didik SMA.

Penggunaan Gaya Bahasa yang Variatif

Hal yang menjadi fokus saat menganalisis gaya bahasa dalam novel Anak Rantau adalah (1) bahasa yang digunakan pengarang;

penggunaan ungkapan;

penggunaan majas; dan penggunaan peribahasa.

Bahasa yang digunakan pengarang, dalam novel Anak Rantau, mayoritas bahasa yang digunakan oleh pengarang adalah bahasa Indonesia yang lazim (umum). Hal tersebut terlihat dalam kutipan berikut.

"Percuma badan besar, tapi hanya berani sama anak-anak kecil. Lepaskan kami! Lawanlah bapak-bapak kami kalau benar jantan," teriak Hepi kepada sosok beringas berbadan lebar itu. ... (Fuadi, 2018:1).

Selain adanya penggunaan bahasa Indonesia yang sudah umum tersebut, dalam novel Anak Rantau pengarang juga menggunakan beberapa kata arkais, kosakata dari bahasa Arab, dan kosakata dari bahasa Minang (hal tersebut telah dipaparkan dalam sub-sub bagian pembahasan sebelumnya).
Adanya penggunaan bahasa yang demikian, membuat novel Anak Rantau memiliki nilai plus jika dijadikan bahan ajar apresiasi sastra untuk SMA. Hal tersebut karena, dengan adanya penggunaan bahasa yang variatif tersebut, membuat novel ini memiliki kesesuaian dengan tingkat penguasaan bahasa peserta didik SMA.

Penggunaan Ungkapan, dalam novel Anak Rantau ditemukan adanya 15 ungkapan yang digunakan oleh pengarangnya. Ungkapan-ungkapan yang dimaksud meliputi naik daun; kutu buku; haus darah; otak encer; anak bawang; sepenuh hati; pecah telur; melawan arus; berkeras hati; kelinci percobaan; memutar otak; kambing hitam; keras kepala; angkat kaki; dan besar hati. Adanya penggunaan beberapa ungkapan membuat novel ini memiliki nilai plus jika dijadikan bahan ajar apresiasi sastra untuk SMA. Hal tersebut karena dengan adanya penggunaan ungkapan-ungkapan tersebut, novel Anak Rantau memiliki kesesuaian dengan tingkat penguasaan bahasa peserta didik SMA.

Penggunaan Majas, dalam novel Anak Rantau ditemukan adanya penggunaan beberapa majas oleh pengarang. Majas-majas yang dimaksud yaitu majas perbandingan (simile, metafora, dan personifikasi), majas pengontrasan (hiperbola dan paradoks) dan majas pertautan (metonimi dan sinekdoke yang berjenis pras pro toto). Adanya penggunaan majas yang variatif tersebut, membuat novel ini memiliki nilai plus jika dijadikan bahan ajar apresiasi sastra untuk SMA. Hal tersebut karena, dengan adanya penggunaan majas tersebut, novel Anak Rantau memiliki kesesuaian 
dengan tingkat penguasaan bahasa peserta didik SMA.

Penggunaan peribahasa, dalam novel Anak Rantau ditemukan adanya lima peribahasa yang digunakan oleh pengarangnya. Adanya penggunaan beberapa peribahasa tersebut membuat novel ini memiliki nilai plus jika dijadikan bahan ajar apresiasi sastra untuk SMA. Hal tersebut karena, dengan adanya penggunaan peribahasa tersebut, novel Anak Rantau memiliki kesesuaian dengan tingkat penguasaan bahasa peserta didik SMA.

Tidak Ditemukannya Satuan Bahasa yang Bernilai Kasar

Dalam novel Anak Rantau tidak ditemukan adanya penggunaan satuan bahasa yang bernilai kasar. Oleh karena itu, novel ini layak digunakan sebagai bahan ajar apresiasi sastra untuk SMA.

\section{Tingkat Keterbacaan}

Menurut Haryadi (2014:164) salah satu cara yang dapat digunakan untuk mengukur tingkat keterbacaan suatu wacana adalah dengan cara mengukurnya dengan menggunakan formula (grafik) Fry dan Raygor. Faktor panjang pendeknya kalimat dan kata-kata sulit masih digunakan pada kedua grafik ini. Namun bedanya, grafik Fry menentukan kata sulit berdasarkan dari jumlah suku kata, sedangkan grafik Raygor menentukan kata sulit berdasarkan jumlah huruf yang membentuk sebuah kata.

Saat dianalisis tingkat keterbacaannya dengan menggunakan formula (grafik) Fry, novel Anak Rantau berada pada daerah (kelas) 9, yang berarti tingkat kelas pembaca yang diprediksi sudah sesuai membaca novel tersebut dimulai dari tingkat (kelas) 8 (9-1), 9 , atau $10(9+1)$. Saat dianalisis tingkat keterbacaannya dengan menggunakan formula (grafik) Raygor, novel ini berada pada daerah (kelas) 11, yang berarti pembaca yang diprediksi sesuai untuk membaca novel Anak Rantau adalah pembaca yang berada pada tingkat (kelas) 10 $(11-1), 11$, atau $12(11+1)$. Oleh karena itu, berdasarkan hasil pengukuran tingkat keterbacaan tersebut disimpulkan novel ini dapat dijadikan sebagai bahan ajar apresiasi sastra tingkat SMA.

\section{Ditinjau dari Aspek Psikologi Pembaca}

Dalam novel Anak Rantau ditemukan adanya isi cerita yang sesuai dengan tingkat psikologi pembaca (peserta didik SMA). Hal tersebut sesuai dengan teori yang diungkapkan oleh Rahmanto yang menyatakan bahwa saat memilih bahan ajar sastra salah satu hal yang harus diperhatikan adalah kesesuaiannya dengan tingkat psikologi peserta didik (Rahmanto, 1988:29). Selain itu, dalam novel Anak Rantau juga ditemukan hal lain yang mendukung kelayakan novel ini jika digunakan sebagai bahan ajar sastra. Hal yang dimaksud yaitu tidak ditemukan muatan cerita (terlebih lagi yang mendominasi dan "ekstrem") yang dapat mempengaruhi perkembangan psikologi peserta didik ke arah yang salah atau menyimpang. Berikut ini adalah paparan tentang temuan terkait aspek psikologi dalam novel Anak Rantau yang mampu mendukung kelayakan novel tersebut jika digunakan sebagai bahan ajar sastra (apresiasi sastra). 
Adanya Muatan Cerita yang mampu Membuat Pembaca Berpikir Kritis

Dalam novel Anak Rantau muatan ini dapat terlihat dari salah satu permasalahan yang ada dalam novel tersebut. Permasalahan yang dimaksud yaitu permasalah siapa tokoh yang mendalangi kasus pengedaran narkoba di kampung Tanjung Durian. Dalam novel ini, permasalahan tersebut baru terungkap di bab ke 26, Anak Hilang. Dalam bab tersebut, akhirnya terungkap bahwa tokoh yang mendalangi permasalahan itu adalah Lenon.

Permasalahan ini dapat membuat pembaca berpikir kritis karena pengarang dari awal hingga menjelang akhir cerita tidak memberikan tanda apapun terkait keterlibatan tokoh Lenon dalam masalah tersebut. Selain itu, pengarang juga memperlihatkan perilaku-perilaku positif yang dilakukan oleh tokoh Lenon untuk mengurangi atau bahkan menghilangkan kecurigaan pembaca terhadap tokoh tersebut. Perilakuperilaku positif yang dimaksud yaitu (1) rutin berziarah ke makam ibunya yang baru saja meninggal; (2) sering ikut salat berjamaah; (3) ikut mengajikan orang yang telah meninggal dunia; dan (4) ikut serta dalam menjaga keamanan kampung (ikut ronda malam).

Dengan hasil analisis yang demikian, novel Anak Rantau memiliki nilai plus jika dijadikan bahan ajar apresiasi sastra untuk SMA. Hal tersebut karena dengan adanya muatan isi cerita yang demikian, membuat novel tersebut memiliki kesesuaian dengan tingkat psikologi peserta didik (SMA) yang sedang berada pada tingkat generalisasi (mulai tertarik menemukan konsepkonsep abstrak dengan menganalisis suatu fenomena).

Adanya Ketertarikan Individu (Tokoh) terhadap Hubungan Baru yang Lebih Matang dengan Teman Sebaya (Tokoh Lain)

Dalam novel Anak Rantau ditemukan empat data terkait muatan ini. Tiga kali menunjukkan adanya ketertarikan tokoh Hepi terhadap tokoh Puti, dan satu kali menunjukkan adanya ketertarikan tokoh Martiaz terhadap tokoh Ibu lbet.

Salah satu bukti adanya ketertarikan Hepi terhadap Puti dalam novel ini dapat terlihat pada halaman 289-290. Sedangkan bukti ketertarikan Martiaz terhadap lbu lbet terlihat pada halaman 356-357.

Berdasarkan hasil analisis yang telah dipaparkan dalam sub-sub bagian ini, dapat disimpulkan novel Anak Rantau memiliki nilai plus jika dijadikan bahan ajar apresiasi sastra untuk SMA. Hal tersebut karena dengan adanya muatan isi cerita yang demikian membuat novel tersebut sesuai dengan tingkat psikologi peserta didik (SMA) yang sedang berada pada tingkat remaja (tertarik terhadap hubungan baru yang lebih matang dengan teman sebaya).

Adanya Kehidupan dalam Masyarakat Lengkap dengan Sistem Etika dan/atau Peranan Sosial Individu dalam Masyarakat tersebut

Dalam novel Anak Rantau ditemukan tiga data yang menunjukkan adanya muatan cerita berupa etika dalam masyarakat dan empat belas data yang menunjukkan adanya muatan cerita berupa peranan sosial individu dalam masyakarat. 
Salah satu contoh etika dalam masyarakat yang termuat dalam novel Anak Rantau dapat terlihat pada halaman 18-19 (etika bertamu ke rumah orang lain). Sedangkan salah satu contoh peranan sosial dalam novel tersebut dapat terlihat pada halaman 275 (peranan sosial seorang polisi).

Berdasarkan hasil analisis yang telah dipaparkan dalam sub-sub bagian ini, dapat disimpulkan novel Anak Rantau memiliki nilai plus jika dijadikan bahan ajar apresiasi sastra untuk SMA. Hal tersebut karena, dengan adanya muatan isi cerita yang demikian membuat novel tersebut sesuai dengan tingkat psikologi peserta didik SMA yang sedang berada pada tingkat remaja (sedang memahami kehidupan dalam masyarakat, termasuk sistem etika dan peranan sosial yang ada di dalamnya).

Adanya Kemandirian dan Kedewasaan Seorang Tokoh dalam Menjalani Kehidupan

Dalam novel Anak Rantau ditemukan 14 data yang menunjukkan adanya muatan ini. Dari empat belas data tersebut, sebanyak tiga data menunjukkan adanya kemandirian seorang tokoh dalam menjalani kehidupan dan sebelas data menunjukkan adanya kedewasaan seorang tokoh dalam menjalani kehidupan.

Dalam novel ini, salah satu contoh kemandirian seorang tokoh dalam menjalani kehidupan dapat terlihat pada halaman 77-78 (bekerja untuk mengumpulkan uang hasil keringatnya sendiri). Sedangkan salah satu contoh kedewasaan tokoh dalam novel ini dapat dilihat pada halaman 262-263 (mampu mengubur amarah dan dendam yang dimilikinya dengan cara mengikhlaskan dan memaafkan).

Berdasarkan hasil analisis yang telah dipaparkan sebelumnya, dapat disimpulkan novel Anak Rantau memiliki nilai plus jika dijadikan bahan ajar apresiasi sastra untuk SMA. Hal tersebut karena dengan adanya muatan isi cerita yang demikian membuat novel tersebut sesuai dengan tingkat psikologi peserta didik SMA (tingkat remaja; sedang memasuki tahap pencapaian kemandirian dan kedewasaan dalam fase perkembangannya).

Tidak Ditemukan Muatan Cerita (Terlebih Lagi yang Mendominasi dan "Ekstrem") yang dapat Mempengaruhi Perkembangan Psikologi Peserta Didik SMA ke Arah yang Salah atau Menyimpang

Dalam novel Anak Rantau tidak ditemukan muatan cerita (terlebih lagi yang mendominasi dan "ekstrem") yang dapat mempengaruhi perkembangan psikologi peserta didik SMA ke arah yang salah atau menyimpang. Meskipun begitu, perlu digarisbawahi peran pendidik dalam membimbing peserta didik tetap sangat diperlukan saat menggunakan novel ini sebagai bahan ajar. Hal tersebut perlu diperhatikan supaya peserta didik tidak asal mencontoh perilaku-perilaku yang ada dalam novel tersebut, mengingat suatu novel tidak mungkin terlepas dari konflik atau permasalahan yang pada dasarnya merupakan bagian dari keseluruhan isi ceritanya.

\section{Ditinjau dari Aspek Latar Belakang Budaya}

Menurut Rahmanto (1988:31) salah satu indikator bahan ajar sastra 
yang baik adalah bahan ajar yang memuat latar belakang budaya (kebudayaan) yang erat dengan kebudayaan peserta didik (dikenal oleh peserta didik). Selain itu, harus dipastikan dalam bahan ajar tersebut tidak ada muatan berupa kebudayaan menyimpang yang dieskpos secara vulgar atau mendalam.

Berdasarkan analisis yang telah dilakukan, dalam novel Anak Rantau ditemukan latar belakang budaya yang erat kaitannya dengan latar belakang budaya di Indonesia. Latar belakang budaya yang dimaksud meliputi cara berpikir masyarakat; kebiasaan atau tradisi; aspek geografis; etika; mainan tradisional; mata pencaharian/pekerjaan; kepercayaan terhadap hal-hal mistis; surat kabar; makanan; kesenian; tokoh-tokoh besar bangsa Indonesia; gotong-royong; peristiwa bersejarah bangsa Indonesia; dan masalah narkoba.

Berdasarkan temuan yang telah diuraikan sebelumnya, disimpulkan terdapat keterkaitan yang erat antara latar belakang budaya dalam novel Anak Rantau dengan latar belakang budaya di Indonesia. Oleh karena itu, dapat dikatakan novel Anak Rantau layak dijadikan bahan ajar apresiasi sastra untuk tingkat SMA, terlebih lagi untuk SMA yang ada di Indonesia. Ditambah lagi dalam novel ini tidak ditemukan adanya muatan cerita berupa kebudayaan menyimpang yang dieskpos secara vulgar atau mendalam.

\section{Ditinjau dari Kesesuaiannya dengan Kompetensi Dasar (KD) Bahasa Indonesia (SMA)}

Saat ditinjau dari kesesuaiannya dengan KD Bahasa Indonesia (SMA), novel Anak Rantau sesuai digunakan untuk membelajarkan lima KD. KD-KD yang dimaksud yaitu (1) KD 3.9 kelas X; (2) KD 3.18 kelas X; (3) KD 3.11 kelas XI; (4) KD 3.20 kelas XI; dan (5) KD 3.9 kelas XII. Dengan demikian, disimpulkan novel ini layak dijadikan bahan ajar apresiasi sastra (SMA).

\section{Ditinjau dari Kesesuaiannya dengan Tuntutan berupa Muatan (Nilai-Nilai) Pendidikan Karakter}

Dalam novel Anak Rantau ditemukan 12 nilai religius, 3 nilai jujur, 1 nilai toleransi, 1 nilai disiplin, 3 nilai kerja keras, 1 nilai kreatif, 2 nilai mandiri, 3 nilai demokratis, 2 nilai rasa ingin tahu, 1 nilai semangat kebangsaan, 2 nilai cinta tanah air, 3 nilai menghargai prestasi, 4 nilai bersahabat/komunikatif, 1 nilai cinta damai, 2 nilai gemar membaca, 3 nilai peduli lingkungan, 5 nilai peduli sosial, dan 2 nilai tanggung jawab. Dengan demikian, disimpulkan novel ini layak dijadikan bahan ajar apresiasi sastra tingkat SMA.

\section{SIMPULAN}

Berdasarkan hasil penelitian yang telah dipaparkan sebelumnya, dapat disimpulkan (1) novel Anak Rantau sesuai dengan tingkat penguasaan bahasa yang dimiliki oleh peserta didik SMA dan di dalamnya tidak menggunakan satuan bahasa yang bernilai kasar; (2) novel Anak Rantau sesuai dengan tingkat psikologi peserta didik SMA dan di dalamnya tidak memuat cerita yang dapat mempengaruhi perkembangan psikologis peserta didik SMA ke arah yang salah atau menyimpang; (3) 
novel Anak Rantau memuat isi (latar belakang budaya) yang erat kaitannya dengan latar belakang budaya yang ada di Indonesia dan tidak ada muatan cerita berupa kebudayaan menyimpang yang dieskpos secara vulgar atau mendalam; dan (4) novel Anak Rantau sesuai dengan tuntutan kurikulum 2013 Bahasa Indonesia (KD dan pendidikan karakter). Berdasarkan hasil penelitian yang demikian, novel Anak Rantau karya Ahmad Fuadi layak dijadikan sebagai bahan ajar apresiasi sastra untuk tingkat SMA.
Berdasarkan hasil simpulan yang telah dipaparkan sebelumnya, penulis menyarankan kepada guru Bahasa Indonesia SMA untuk memanfaatkan novel Anak Rantau sebagai inovasi dalam pemilihan bahan ajar apresiasi sastra (novel) karena memiliki kualitas yang baik atau layak dijadikan sebagai bahan ajar tersebut. Inovasi itu perlu dilakukan agar novel yang digunakan sebagai bahan ajar tidak hanya novel yang itu-itu saja, sehingga peserta didik SMA juga dapat mengikuti perkembangan novel.

\section{DAFTAR PUSTAKA}

$\begin{array}{ccr}\text { Aminuddin. } & \text { (2015). } & \text { Pengantar } \\ \text { Apresiasi } & \text { Karya } & \text { Sastra. } \\ \text { Bandung: } & \text { Sinar } & \text { Baru } \\ \text { Algensindo. } & & \end{array}$

Fuadi, A. (2018). Anak Rantau. Jakarta: PT Falcon.

Haryadi. (2014). Dasar-Dasar Membaca:

Bermuatan

Kreativitas Berpikir dan NilaiNilai Pendidikan Karakter. Semarang: Universitas Negeri Semarang.

Kemendikbud. (2016). Silabus Mata Pelajaran Bahasa Indonesia Sekolah Menengah Atas/ Madrasah Aliyah/Sekolah Menengah Kejuruan/Madrasah Aliyah Kejuruan (SMA/MA/SMK MAK). Jakarta: Kementerian Pendidikan dan Kebudayaan.

Praptiwi, F.N. (2017). Pendidikan Karakter Tokoh Utama dalam Novel Cahaya Cinta Pesantren Karangan Ira Madan dan Semester Pertama di Malory Towers Karangan Enid Blyton. 1(2): 234-252. Aksis: Jurnal Pendidikan Bahasa dan Sastra Indonesia. http://journal.unj.ac.id/ unj/index.php/aksis/article/downl oad/5304/3946

Rahmanto, B. (1988). Metode Pengajaran Sastra. Yogyakarta: Kanisius.

Sugiyono. (2016). Metode Penelitian Pendidikan: Pendekatan Kuantitatif, Kualitatif, dan R\&D. Bandung: Alfabeta.

Suherli, Suryaman, M., Septiaji, A., \& Istiqomah. (2017). Bahasa Indonesia: SMA/MA/SMK/MAK Kelas XI: Edisi Revisi 2017. Diakses tanggal 26 April 2019 dari https://drive.google.com/file /d/13AIpIOUMI62K4GC7wf8MUq 6xuvwQFtq6/view

Suherli, Suryaman, S., Septiaji A., \& Istiqomah. (2016). Bahasa Indonesia SMA/MA/SMK/MAK Kelas X: Edisi Revisi 2016. Jakarta: Pusat Kurikulum dan Perbukuan, Balitbang, Kemendikbud.

Suryaman, M., Suherli, \& Istiqomah. (2018). Bahasa Indonesia: SMA/MA/SMK/MAK Kelas XII: Edisi Revisi 2018. Diakses tanggal 1 Januari 2019 dari https://drive.google.com/file/d/1hr 
ZC1rOFEvbBDrTzkkomMu7kDg

Cy10Uh/view

Wicaksono, A., Setyaningsih, N.H., \&

Sumartini. (2014). Novel Negeri

5 Menara Karya Ahmad Fuadi sebagai Pilihan Bahan Ajar

Sastra Indonesia di SMA. 3 (1):

1-9. Jurnal Sastra Indonesia.

https://journal.unnes.ac.id/sju/ind

ex.php/jsi/article/view/3990 